\title{
PENGARUH PEMBERIAN INFORMASI MELALUI MEDIA BOOKLET TERHADAP TINGKAT KEPATUHAN PASIEN DM TIPE 2
}

The Effect of Providing Information Through Media Booklets on Compliance Levels of Type 2 DM Patients

\author{
Ni Ketut Puspita Sari1, I Nyoman Sutresna', Alfiery Leda Kio1, I Nyoman Ariyoga ${ }^{2}$ \\ 1STIKES Bina Usada Bali \\ 2STAHN Mpu Kuturan Singaraja \\ *) itapuspita04193@gmail.com
}

\begin{abstract}
Adherence is a major component of successful diabetes treatment which is influenced by knowledge and skills regarding disease management. Providing information through health education using a multimedia approach can help patients to master information more effectively, one example is using booklets. This study purposed to determine the effect of providing information through booklet media on the compliance level of type 2 DM patients. This study used a pre-experimental method with a One group pre-test-posttest design. This study included 36 samples selected by purposive sampling technique. Data collection using questionnaires, data analysis consists of univariate and bivariate analysis. This study showed the most results were 29 people or $80.6 \%$ were less obedient during the pre-test and the most were 34 people or $94.4 \%$ were obedient during the post-test. The results of the Wilcoxon sign rank test obtained Zstats $=4,949>$ Ztable $=1.96$ and $P$-value $=0.001<\alpha 0.05$, this result can be concluded that the provision of information through the media booklet has a significant effect on the level of compliance of type $2 \mathrm{DM}$ patients. It is recommended that the hospital use booklet media when providing information to type 2 DM patients about diabetes mellitus and its treatment therapy, so that the information conveyed can be easier to understand
\end{abstract}

.Keywords : Information, Booklet, Compliance

\section{ABSTRAK}

Kepatuhan merupakan komponen utama keberhasilan pengobatan diabetes yang dipengaruhi oleh pengetahuan dan ketrampilan mengenai pengelolahaan penyakit. Pemberian informasi melalui pendidikan kesehatan dengan menggunakan pendekatan multimedia dapat membantu pasien untuk menguasai informasi dengan lebih efektif, salah satu contohnya menggunakan booklet. Penelitian ini bertujuan untuk mengetahui pengaruh pemberian informasi melalui media booklet terhadap tingkat kepatuhan pasien DM tipe 2. Penelitian ini menggunakan metode pre experimental dengan rancangan One group Pra test-posttest Design. Penelitian ini melibatkan 36 sampel yang dipilih dengan teknik sampel purposive sampling. Pengumpulan data menggunakan kuesioner, analisis data terdiri dari analisis univariat dan bivariat. Penelitian ini menunjukkan hasil paling banyak yaitu 29 orang atau $80,6 \%$ kurang patuh saat pre test dan paling banyak yaitu 34 orang atau $94,4 \%$ patuh saat post test. Hasil Wilcoxon sign rank test didapatkan $Z_{\text {hitung }}=4,949>Z_{\text {tabel }}=1,96$ dan $P$ value $=0,001<a 0,05$ hasil ini dapat disimpulkan bahwa pemberian informasi melalui media booklet berpengaruh signifikan terhadap tingkat kepatuhan pasien DM tipe 2. Disarankan kepada Rumah Sakit agar menggunakan media booklet saat memberikan informasi kepada pasien DM tipe 2 tentang penyakit diabetes mellitus dan terapi pengobatannya, sehingga informasi yang disampaikan dapat lebih mudah dipahami.

Kata kunci : Informasi, Booklet, Kepatuhan

\section{PENDAHULUAN}

Kebiasaan mengkonsumsi makanan cepat saji, seperti makanan dan minuman berkadar gula tinggi, sudah menjadi gaya hidup masyarakat moderen sekarang ini yang kemudian memicu timbulnya penyakit-penyakit akibat pola makan dan minum yang tidak sehat. Salah satu penyakit yang dapat terjadi adalah Diabetes Melitus (DM) (Prihaningtyas, 2017). Diabetes melitus merupakan salah satu penyakit yang cukup menonjol di antara penyakit-penyakit yang lain seperti jantung, kanker serta stroke. Penyakit-penyakit tersebut diakibatkan oleh pola makan, gaya hidup kurang sehat serta tidak diimbangi oleh olahraga yang kemudian memicu menurunnya antibodi dan menyebabkan kerusakan pada organ serta sistem tubuh yang vital. Fenomena dalam kehidupan sekarang, diabetes melitus termasuk salah satu penyakit tidak menular yang telah menjadi masalah serius kesehatan masyarakat, tidak hanya di Indonesia tetapi juga di dunia (Bustan, 2015).

Menurut data dari International Diabetes Federation tahun 2018, jumlah penderita diabetes di seluruh dunia sebanyak 250 juta, dan angka itu akan mencapai 350 juta orang sampai tahun 2030 
(International Diabetes Federation, 2018). Data Riset Kesehatan Dasar (Riskesdas) tahun 2018 menemukan bahwa prevalensi nasional diabetes mellitus adalah $7,7 \%$ dengan prevalensi tertinggi terdapat di Provinsi Kalimantan Barat (15,1\%) sedangkan Provinsi Bali berada di peringkat kelima dengan prevalensi $7,2 \%$ (Kementerian Kesehatan Republik Indonesia, 2018). Data yang diperoleh dari Dinas Kesehatan Provinsi Bali, jumlah penderita diabetes mellitus diseluruh Kabupaten di Bali pada tahun 2017 sebanyak 9258 dan tahun 2018 sebanyak 11.523 kasus. kota Denpasar menempati peringkat pertama dari kota-kota lain yang ada di Bali, dengan jumlah penderita DM tipe II sebanyak 18.837 orang (Dinas Kesehatan Provinsi Bali, 2018).

Diabetes melitus merupakan penyakit yang tidak dapat disembuhkan namun hanya dapat dikendalikan, seseorang yang telah menderita DM untuk dapat mengendalikan gula darah dalam batas normal membutuhkan pengelolahaan yang baik melalui empat pilar manajemen diabetes yaitu edukasi, terapi nutrisi, latihan jasmani dan intervensi farmakologis seperti pengaturan pola makan yang sehat, aktivitas fisik, minum obat yang teratur, pemantauan glukosa darah dan perawatan diri. Keberhasilan pengelolahaan DM untuk mencegah komplikasi dapat dicapai melalui kepatuhan pasien menjalani terapi (Achmad Yoga, 2016). Kepatuhan merupakan komponen utama keberhasilan pengobatan diabetes yang dipengaruhi oleh pengetahuan dan ketrampilan mengenai pengelolahaan penyakit DM (Susilo \& Wulandari, 2015). Hasil penelitian Oktadiansyah dan Yulia (2018) menunjukkan bahwa pasien diabetes melitus yang memiliki kepatuhan rendah minum obat sebanyak $42,9 \%$ di RSUD Cibinong, dari penelitian tersebut diketahui penyebab ketidakpatuhan pasien DM dalam menjalani terapi adalah tidak memahami dan salah memahami tentang manfaat diet, olahraga, dan obat

Dampak yang dapat terjadi apabila pasien tidak patuh menjalani terapi mengakibatkan kadar gula darah yang tidak terkontrol sehingga dapat terjadi komplikasi. Komplikasi diabetes terjadi pada semua organ dalam tubuh yang dialiri pembuluh darah kecil dan besar dengan penyebab kematian 50\% akibat penyakit jantung koroner dan 30\% akibat gagal ginjal. Selain kematian, diabetes mellitus juga menyebabkan kecacatan, yang sangat berhubungan terhadap kualitas hidup dari pasien diabetes mellitus sendiri. Sebanyak $30 \%$ pasien diabetes mellitus mengalami kebutaan akibat komplikasi retinopati dan 10\% harus menjalani amputasi tungkai kaki (Perkumpulan Endokrinologi Indonesia, 2015).

Upaya yang dapat dilakukan untuk meningkatkan kepatuhan pasien DM menjalani terapi dapat dilakukan dengan meningkatkan pengetahuan dan ketrampilan pasien mengenai pengelolahaan penyakit DM dengan memberikan informasi melalui pendidikan kesehatan oleh perawat di ruang perawatan dan di rawat jalan. Pasien yang mendapatkan informasi tentang penyakitnya lebih efektif berpartisipasi dalam proses terapi (Brunner \& Suddart, 2014). Pemberian informasi melalui pendidikan kesehatan merupakan cara yang tepat untuk mengatasi masalah ketidakpatuhan pasien DM, informasi dapat disampaikan dengan beberapa cara berupa media audio dan visual yang dapat digunakan untuk membantu proses belajar. Pendekatan multimedia selama proses belajar dapat membantu pasien untuk menguasai informasi dengan lebih efektif, salah satu contohnya menggunakan booklet. Booklet dapat dipelajari setiap saat karena berbentuk buku dan dapat menyebarkan informasi dalam bentuk tulisan dan gambar, sehingga terlihat lebih menarik dan sangat sesuai digunakan sebagai media edukasi bagi pasien DM tipe 2 (Merlin, 2017). Penelitian Valentina (2018) membuktikan bahwa media booklet dapat meningkatkan kepatuhan pada pasien diabetes melitus tipe 2 di Puskesmas Banjarbaru Selatan. Selain itu, penelitian lainnya dengan hasil yang senada juga dilakukan oleh Sabarudin (2018) juga menemukan pemberian edukasi melalui booklet efektif dapat membantu meningkatkan kepatuhan pengobatan pasien DM tipe 2 di Puskesmas Puuwatu Kota Kediri

Hasil studi pendahuluan yang dilakukan peneliti pada bulan Maret 2020 di Unit pelaksana Teknis Daerah (UPTD) Rumah Sakit Umum Daerah Bali Mandara, didapatkan data jumlah pasien DM tipe 2 yang dirawat tahun 2018 sebanyak 308 orang terdiri dari 229 orang $(74,24 \%)$ dan 79 pasien baru $(25,64 \%)$. Jumlah pasien diabetes mellitus yang dirawat tahun 2019 sebanyak 526 orang terdiri dari 446 orang $(84,79 \%)$ dan 80 pasien baru $(15,20 \%)$. Rata-rata pasien yang dirawat perbulan tahun 2019 sebanyak 42 orang. Berdasarkan wawancara terhadap 10 penderita DM tipe 2 sebanyak tiga orang (30\%) mengatakan kurang patuh mengkonsumsi makanan sesuai diet yang dianjurkan oleh dokter, dua orang $(30 \%)$ sering lupa minum obat dan tiga orang $(30 \%)$ mengatakan jarang berolah raga. Peneliti juga menanyakan kepada penderita DM tipe 2 tentang hasil pemeriksaan kadar glukosa darah sebelumnya dimana semua mengatakan bahwa kadar gula darah mereka pada tes gula darah puasa terakhir, rata-rata lebih dari $200 \mathrm{mg} / \mathrm{dL}$.

Tujuan dari penelitian ini yaitu untuk mengetahui pengaruh pemberian informasi melalui media booklet terhadap tingkat kepatuhan pasien DM tipe 2 di Ruang Kasuari Unit Pelaksana Teknis Rumah Sakit Umum Daerah Bali Mandara. 


\section{METODE}

Jenis penelitian ini adalah pre eksperimental dengan desain One-group Pre test-Post test. Sampel dalam penelitian ini adalah pasien DM tipe 2 yang berkunjung di Ruang Kasuari Unit Pelaksana Teknis Rumah Sakit Umum Daerah Bali Mandara yang memenuhi kriteria inklusi antara lain Pasien yang DM tipe 2 bersedia menjadi responden, pasien yang DM tipe 2 berumur $>20$ tahun, penderita DM tipe 2 yang rutin berkunjung setiap dua minggu sekali ke Ruang kasuari UPTD Rumah Sakit Umum Bali Mandara, pasien yang DM tipe 2 yang menderita DM $>1$ tahun. Sampel dalam penelitian ini sebanyak 36 orang, yang dipilih dengan teknik sampel purposive sampling. Penelitian ini dilakukan di Ruang Kasuari Unit Pelaksana Teknis Rumah Sakit Umum Daerah Bali Mandara pada bulan September sampai dengan bulan Oktober tahun 2020. Pengumpulan data menggunakan kuesioner. Langkah-langkah pengumpulan data dalam penelitian ini meliputi prosedur Administrasi dan prosedur Teknis yaitu menyeleksi calon responden, pre test, memberikan intervensi langsung berupa pemberian informasi melalui media booklet, post test, memberikan reinforcement positif dan tabulasi data. Analisis menggunakan uji Wilcoxon Sign Rank Test

\section{HASIL}

\section{A. Karakteristik Subyek Penelitian}

\section{Karakteristik Responden Berdasarkan Usia}

Tabel 1

Distribusi Karakteristik Responden Berdasarkan Umur di Ruang Kasuari Unit Pelaksana Teknis Rumah Sakit Umum Daerah Bali Mandara Tahun 2020

\begin{tabular}{llll}
\hline No & $\begin{array}{l}\text { Umur (Badan Pusat Statistik } \\
(2015)\end{array}$ & $\mathrm{n}$ & $\%$ \\
\hline 1 & $31-40$ th (dewasa madya) & 3 & 8.3 \\
\hline 2 & $41-50$ th (dewasa akhir) & 20 & 55.6 \\
\hline 3 & $51-60$ th (awal lansia) & 13 & 36.1 \\
\hline Total & 36 & 100 \\
\hline
\end{tabular}

Data Primer 2020

Berdasarkan tabel 1 menunjukkan karakteristik berdasarkan umur, bahwa dari 36 responden sebagian besar berumur 41-50 tahun yaitu sebanyak 20 orang $(55,6 \%)$.

\section{Karakteristik Responden Berdasarkan Jenis Kelamin}

\section{Tabel 2}

Distribusi Karakteristik Responden Berdasarkan Jenis Kelamin di Ruang Kasuari Unit Pelaksana Teknis Rumah Sakit Umum Daerah Bali Mandara Tahun 2020

\begin{tabular}{llll}
\hline No & Jenis Kelamin & $\mathrm{n}$ & $\%$ \\
\hline 1 & Laki-laki & 21 & 58.3 \\
\hline 2 & Perempuan & 15 & 41.7 \\
\hline \multicolumn{2}{l}{ Total } & 36 & 100.0 \\
\hline
\end{tabular}

Data Primer 2020

Berdasarkan tabel 2 menunjukkan karakteristik berdasarkan jenis kelamin, bahwa dari 36 responden sebagian besar laki-laki yaitu sebanyak 21 orang $(58,3 \%)$.

\section{Karakteristik Responden Berdasarkan Pendidikan}

Tabel 3

Distribusi Karakteristik Responden Berdasarkan Pendidikan di Ruang Kasuari Unit Pelaksana Teknis Rumah Sakit Umum Daerah Bali Mandara Tahun 2020

\begin{tabular}{llll}
\hline No & Pendidikan & $\mathrm{n}$ & $\%$ \\
\hline 1 & SD & 6 & 16.7 \\
\hline 2 & SMP & 18 & 50.0 \\
\hline 3 & SMA & 12 & 33.3 \\
\hline \multicolumn{2}{l}{ Total } & 36 & 100.0 \\
\hline Data & Primer 2020
\end{tabular}

Berdasarkan tabel 3 menunjukkan karakteristik berdasarkan pendidikan bahwa dari 36 responden paling banyak berpendidikan SMP yaitu sebanyak 18 orang $(50 \%)$.

\section{Karakteristik Responden Berdasarkan Pekerjaan}

\section{Tabel 4}

Distribusi Karakteristik Responden Berdasarkan Pekerjaan di Ruang Kasuari Unit Pelaksana Teknis Rumah Sakit Umum Daerah Bali Mandara Tahun 2020

\begin{tabular}{llll}
\hline No & Pekerjaan & $\mathrm{N}$ & $\%$ \\
\hline 1 & Tidak & 6 & 16.7 \\
\hline 2 & Swasta & 16 & 44.4 \\
\hline 3 & Wiraswasta & 14 & 38.9 \\
\hline Total & 36 & 100.0 \\
\hline
\end{tabular}

Data Primer 2020

Berdasarkan tabel 4 menunjukkan karakteristik berdasarkan pekerjaan bahwa dari 36 responden 
sebagian besar pekerja swasta yaitu sebanyak 16 orang $(44,4 \%)$.

\section{B. Hasil Univariat}

\section{Tingkat Kepatuhan Pasien DM tipe 2 Sebelum Pemberian Informasi Melalui Media Booklet}

Tabel 5

Tingkat Kepatuhan Pasien DM tipe 2 Sebelum Pemberian Informasi Melalui Media Booklet di Ruang Kasuari Unit Pelaksana Teknis Rumah Sakit Umum Daerah Bali Mandara Tahun 2020

\begin{tabular}{llll}
\hline No & Kepatuhan Pre Test & $\mathrm{n}$ & $\%$ \\
\hline 1 & Patuh & 0 & 0 \\
\hline 2 & Kurang patuh & 29 & 80.6 \\
\hline 3 & Tidak patuh & 7 & 19.4 \\
\hline & Total & 36 & 100 \\
\hline
\end{tabular}

Data Primer 2020

Hasil penelitian yang dilakukan kepada 36 responden sebelum pemberian informasi melalui media booklet menunjukkan bahwa sebanyak 29 orang atau $80,6 \%$ tingkat kepatuhan pasien DM tipe 2 dalam kategori kurang patuh.

\section{Tingkat Kepatuhan Pasien DM tipe 2 Setelah} Pemberian Informasi Melalui Media Booklet

Tabel.6

Tingkat Kepatuhan Pasien DM tipe 2 Setelah Pemberian Informasi Melalui Media Booklet di Ruang Kasuari Unit Pelaksana Teknis Rumah Sakit Umum Daerah Bali Mandara Tahun 2020

\begin{tabular}{llll}
\hline No & Kepatuhan Post Test & $\mathrm{n}$ & $\%$ \\
\hline 1 & Patuh & 34 & 94.4 \\
\hline 2 & Kurang patuh & 2 & 5.6 \\
\hline 3 & Tidak patuh & 0 & 0 \\
\hline & Total & 36 & 100 \\
\hline
\end{tabular}

Data Primer 2020

Hasil penelitian yang dilakukan kepada 36 responden setelah pemberian informasi melalui media booklet menunjukkan bahwa sebanyak 34 orang atau 94,4 \% tingkat kepatuhan pasien DM tipe 2 dalam kategori patuh.

\section{Hasil Bivariat}

Tabel 7

Hasil Analisis pengaruh Pemberian Informasi Melalui Media Booklet Terhadap Tingkat Kepatuhan Pasien DM tipe 2 di Ruang Kasuari Unit Pelaksana Teknis Rumah Sakit
Umum Daerah Bali Mandara

\begin{tabular}{llll}
\hline & $\begin{array}{l}\text { Median } \\
\text { (Minimum- } \\
\text { Maksimum) }\end{array}$ & Z $_{\text {hitung }}$ & p value \\
\hline $\begin{array}{l}\text { Kepatuhan } \\
\begin{array}{l}\text { Pre test } \\
\text { Kepatuhan }\end{array}\end{array}$ & $35(25-39)$ & & \\
Post test & $51(38-57)$ & 5,238 & 0,001 \\
\hline
\end{tabular}

Sumber : Data Primer 2020

Hasil Analisa data berdasarkan table di atas menunjukkan hasil uji statistik Wilcoxon Sign Rank Test didapatkan $Z_{\text {hitung }}=5,23>Z_{\text {tabel }}=1,96$ dan $P$ value $=0,001<\alpha 0,05$ hasil ini menunjukkan bahwa $\mathrm{H}_{0}$ d8itolak yang artinya ada pengaruh pemberian informasi melalui media booklet terhadap tingkat kepatuhan pasien DM tipe 2 di Ruang Kasuari Unit Pelaksana Teknis Rumah Sakit Umum Daerah Bali Mandara.

\section{PEMBAHASAN}

A. Tingkat Kepatuhan Pasien DM tipe 2 Sebelum Pemberian Informasi Melalui Media Booklet di Ruang Kasuari Unit Pelaksana Teknis Rumah Sakit Umum Daerah Bali Mandara

Hasil penelitian menunjukkan sebelum pemberian informasi melalui media booklet menunjukkan bahwa sebanyak 29 orang atau $80,6 \%$ tingkat kepatuhan pasien DM tipe 2 dalam kategori kurang patuh. Kepatuhan pasien DM tipe 2 yang menjadi responden pada penelitian ini diukur berdasarkan indikator pemantauan glukosa darah, penyesuaian diet, keteraturan latihan/aktifitas fisik dan keteraturan kunjungan berobat. Pasien DM tipe 2 kurang patuh dalam menjalani terapi, Menurut Achmad Yoga (2016) Diabetes melitus merupakan penyakit yang tidak dapat disembuhkan namun hanya dapat dikendalikan, sehingga memerlukan pengetahuan pasien tentang perawatan DM. Pengetahuan merupakan salah satu faktor yang menyebabkan terbentuknya kepatuhan. Pengetahuan yang harus dimiliki oleh pasien DM tipe 2 meliputi arti penyakit DM, penyebab, gejala yang ditimbulkan dan pentingnya melakukan perawatan seperti pemantauan glukosa darah, penyesuaian diet, keteraturan latihan/aktifitas fisik dan keteraturan kunjungan berobat serta bahaya dari komplikasi akibat dari DM. Pengetahuan yang baik tentang $\mathrm{dm}$ dapat memotivasi pasien untuk berpartisipasi dalam memodifikasi gaya hidup yang lebih sehat. 
Menurut Waluya (2016) pasien DM kurang patuh dalam merawat kesehatan diri sendiri meliputi pemantauan glukosa darah, penyesuaian diet, keteraturan latihan/aktifitas fisik dan keteraturan kunjungan berobat disebabkan karena perawatan kesehatan yang lama merupakan beban dilihat dari segi biaya yang harus dikeluarkan serta adanya efek samping obat walaupun ringan tetap akan memberikan rasa tidak enak terhadap penderita. Sukar untuk menyadarkan penderita untuk terus melakukan perawatan kesehatan selama jangka waktu yang ditentukan, karena jangka waktu perawatan kesehatan yang ditetapkan lama maka terdapat beberapa kemungkinan pola kepatuhan penderita yaitu penderita perawatan kesehatan teratur, penderita tidak melakukan perawatan kesehatan secara teratur, penderita sama sekali tidak melakukan perawatan kesehatan.

Tingkat kepatuhan pasien DM, bila dihubungkan dengan variabel yang mempengaruhi tingkat kepatuhan menurut Bidari, (2014) yaitu jenis kelamin, responden pada penelitian ini berdasarkan jenis kelamin sebagian besar laki-laki yaitu sebanyak 21 orang (58,3\%). Menurut Bidari, (2014) laki-laki memiliki kepatuhan yang lebih rendah dibandingkan perempuan. Kecenderungan laki-laki lebih tinggi untuk mangkir berobat kemungkinan karena laki-laki aktivitasnya lebih tinggi dalam sehari-harinya, serta laki-laki merupakan tulang punggung keluarga yang harus bekerja.

Tingkat kepatuhan pasien DM, bila dihubungkan dengan faktor usia, dimana hasil penelitian tentang karakteristik responden berdasarkan usia menunjukkan sebagian besar berumur 41-50 tahun yaitu sebanyak 20 orang $(55,6 \%)$ dimana usia ini termasuk rentang usia dewasa akhir. Niven (2014) menyatakan usia masih merupakan masalah yang kontroversial dalam hubungan dengan ketidakpatuhan. Di kalangan usia muda, cenderung mempunyai tingkat kepatuhan yang buruk terhadap pengobatan. Alasan untuk hal ini kemungkinan bahwa pada dewasa madya dan dewasa akhir sehubungan dengan segala bentuk terapi atau dalam mengatur perjanjian mereka mengganggap dirinya istimewa dan berbeda dengan orang lain sehingga mereka cenderung meremehkan segala bentuk aturan yang salah satunya menyangkut aturan terapi. Berbeda halnya pada usia awal lansia cenderung mempunyai tingkat kepatuhan yang tinggi terhadap pengobatan disebabkan karena pada usia awal lansia lebih menghargai dirinya dan cenderung lebih memberhatikan nasehat yang diberikan oleh tenaga kesehatan.

Tingkat kepatuhan pasien TB minum obat, bila dihubungkan dengan pendidikan pada penelitian ini sebagian besar berpendidikan SMP yaitu sebanyak 18 orang $(50 \%)$. Hasil penelitian ini sesuai dengan pendapat Bidari, (2014) pendidikan merupakan salah satu faktor yang dapat mempengaruhi kepatuhan karena semakin tinggi tingkat pendidikan seseorang semakin mudah menerima informasi, sebaliknya pendidikan yang kurang akan menghambat perkembangan sikap seseorang terhadap nilai-nilai baru yang diperkenalkan. Pendidikan akan berpengaruh pada pengetahuan dan informasi yang dimiliki responden. Tingkat pendidikan sangat berpengaruh terhadap kemampuan penderita untuk menerima informasi tentang penyakit, terutama DM. Kurangnya informasi tentang penyakit DM menyebabkan kurangnya pengertian penderita terhadap penyakit dan bahayanya sehingga menyebabkan berkurangnya kepatuhan penderita terhadap pengobatan atau berhenti berobat bila gejala penyakit tidak dirasakan lagi. Pada penelitian ini baik responden yang berpendidikan SD, SMP dan SMA sama-sama kurang patuh, hal ini dapat disebabkan karena kemampuan seseorang untuk mengingat informasi yang pernah didapatkan serta setiap orang juga mempunyai kemampuan yang tidak sama dalam menerima materi atau informasi tentang penyakit DM, ada yang mudah dalam menerima informasi yang didapat. Terkadang ada juga yang tidak begitu memperhatikan materi atau informasi yang telah diberikan, mereka menganggap semua itu hal yang tidak penting buat dirinya.

Karakteristik berdasarkan pekerjaaan sebagian besar pekerja swasta yaitu sebanyak 16 orang (44,4\%). Sesuai dengan pendapat Niven (2014) karakteristik pekerjaan terkait dengan waktu bekerja dan penghasilan yang diperoleh, bahwa uang dan waktu merupakan faktor yang tidak dapat diabaikan dalam kepatuhan program-program medis. Resonden pada penelitian ini kurang patuh dapat disebabkan karena aktivitas mereka yang tinggi dalam bekerja dapat menyebabkan mereka lupa untuk melakukan perawatan diri.

Menurut peneliti, selain faktor demografi salah satu faktor yang cukup berpengaruh terhadap kepatuhannya untuk minum obat yaitu pengalaman pribadi responden. Dalam hal ini pengalaman pribadi 
yang dimaksud yaitu pengalaman tentang efek samping dari OAT. Berdasarkan pengamatan di lapangan pada saat penelitian, ada beberapa orang dari responden yang masih mengeluhkan tentang efek samping setelah minum OAT, terutama mual muntah. Meskipun mereka telah minum OAT lebih dari 2 bulan, namun masih ada sebagian responden yang tetep merasakan gejala tersebut. Hal inilah yang cukup berpengaruh terhadap kepatuhan pasien untuk minum obat, karena mereka seakan-akan merasa trauma dengan efek samping yang timbul setelah minum obat. Selain karena merasa kurang nyaman, efek samping tersebut juga terkadang dapat mengganggu aktivitas mereka. Mengingat aktivitas sebagian besar responden adalah sebagai wiraswasta, maka dengan terganggunya aktivitas ini juga akan berpengaruh terhadap penghasilan mereka. Dan responden baru akan mengunjungi fasilitas pelayanan kesehatan jika efek samping yang dirasakan tersebut semakin parah.

Peneliti berpendapat, faktor lain yang mempengaruhi kepatuhan pasien DM selain pengalaman pribadi adalah persepsi keseriusan pasien terhadap penyakitnya yang rendah disebabkan oleh persepsi dan keyakinan responden sendiri tentang kondisinya mereka sudah jauh lebih baik daripada saat mulai sakit. Berdasarkan hasil wawancara pada saat penelitian, hampir seluruh responden mengatakan bahwa mereka mengalami perkembangan kondisi yang cukup signifikan. Hal ini bisa dirasakan dengan berkurangnya gejala seperti mudah letih, banyak makan (polyphagia), banyak minum (polydipsi) dan banyak kencing (polyuria) dan kadar gula darah sudah stabil. Sebagian besar dari mereka pasti akan merasa bahwa mereka sudah sembuh jadi mereka mempunyai anggapan bahwa tidak perlu lagi rutin berobat. Hal ini juga tentu akan berpengaruh terhadap motivasi mereka untuk melakukan kunjungan ke Rumah Sakit atau puskesmas. Apalagi didukung dengan kesibukan mereka bekerja yang tentu akan lebih banyak menyita waktu mereka dan kewajiban mereka untuk kontrol sesuai jadwal akhirnya kurang begitu diperhatikan lagi.

Ketidakpatuhan pasien DM dibuktikan oleh beberapa penelitian sebelumnya salah satunya dilakukan oleh Hayati. (2015) tentang kepatuhan berobat penderita diabetes mellitus tipe 2 di Puskesmas Kecamatan Pancoran Mas Depok, hasil penelitian menunjukkan sebagian besar responden termasuk dalam kategori tidak patuh berobat yaitu sebanyak 24 orang $(67 \%)$. Penelitian Oktadiansyah dan Yulia (2018) menunjukkan bahwa pasien diabetes melitus yang memiliki kepatuhan rendah minum obat sebanyak $42,9 \%$ di RSUD Cibinong, dari penelitian tersebut diketahui penyebab ketidakpatuhan pasien DM dalam menjalani terapi adalah tidak memahami dan salah memahami tentang manfaat diet, olahraga, dan obat.

\section{B. Tingkat Kepatuhan Pasien DM tipe 2 setelah Pemberian Informasi Melalui Media Booklet di Ruang Kasuari Unit Pelaksana Teknis Rumah Sakit Umum Daerah Bali Mandara}

Hasil penelitian menunjukkan setelah pemberian informasi melalui media booklet menunjukkan bahwa sebanyak 34 orang atau $94,4 \%$ tingkat kepatuhan pasien DM tipe 2 dalam kategori patuh. Hasil penelitian ini menunjukkan tingkat kepatuhan pasien mengalami peningkatan setelah diberikan informasi melalui media booklet karena informasi yang disampikan khususnya pengetahuan tentang DM yang dapat meningkatkan pemahaman pasien tentang penyakit DM. Hal ini sesuai dengan teori Delaune \& Ladner (2016) strategi untuk meningkatkan kepatuhan diantaranya pemberian informasi dan dukungan profesional kesehatan. Pemberian informasi yang jelas pada pasien mengenai penyakit yang dideritanya serta cara pengobatannya dapat meningkatkan pengetahuan, mengubah perilaku, memberikan motivasi dan meningkatkan kepatuhan pasien. Dukungan profesional kesehatan sangat diperlukan untuk meningkatkan kepatuhan, contoh yang paling sederhana dalam hal dukungan tersebut adalah dengan adanya teknik komunikasi. Komunikasi memegang peranan penting karena komunikasi yang baik diberikan oleh profesional kesehatan baik Dokter/perawat dapat menanamkan kepatuhan pasien untuk berobat, komunikasi antara petugas dan pasien bisa dilakukan melaui pemberian informasi tentang penyakit DM.

Terjadi peningkatan kepatuhan setelah diberikan informasi melalui media booklet karena berisi informasi yang jelas, tegas dan mudah dimengerti selain itu juga berisi tulisan dan gambar. Hal ini sesuai dengan teori Susilana dan Rian (2014) pendidikan kesehatan menggunakan media booklet dapat meningkatkan pengetahuan. Booklet merupakan alat bantu berbentuk buku, dilengkapi dengan tulisan maupun gambar yang disesuaikan 
dengan sasaran pembacanya. Informasi yang ada dalam booklet disusun dengan jelas dan rinci sehingga dapat ditangkap dengan baik oleh sasaran pendidikan dan tidak menimbulkan kesalahan persepsi. Penggunaan media booklet sebagai alat bantu dalam pemberian edukasi kepada pasien DM, akan membuat sasaran pendidikan lebih mudah memahami informasi yang disampaikan dibandingkan penyampaian informasi hanya secara lisan, karena sasaran pendidikan dapat mengamati langsung gambar dan tulisan yang merupakan penjelasan terhadap gambar yang ada dalam media tersebut.

Menurut peneliti, pemberian edukasi melalui booklet dapat membantu meningkatkan kepatuhan pasien DM. Informasi yang terdapat dalam booklet dapat lebih banyak dan lebih terperinci sehingga penyampaian informasi mengenai DM dapat mempermudah pasien dalam memahami penyakit dan pengobatannya. Ada beberapa Keunggulan atau kelebihan media booklet ini adalah informasi disajikan dengan lengkap mengenai topik tertentu serta didukung oleh gambar yang menarik sehingga merangsang seseorang untuk membacanya, mempunyai jangkauan yang luasdan mudah dalam penyampaiannya.

Peningkatan kepatuhan pasien DM setelah pemberian informasi melalui media booklet dibuktikan oleh beberapa penelitian sebelumnya salah satunya dilakukan oleh Valentina (2018) tentang pengaruh edukasi melalui media booklet terhadap pengetahuan dan kepatuhan pasien diabetes melitus tipe 2 di Puskesmas Banjarbaru Selatan. Hasil penelitian menunjukkan kepatuhan rendah terjadi penurunan yaitu pada pretest sebanyak 17 responden dan setelah post test menjadi 4 responden hal tersebut menunjukkan tingkat kepatuhan yang sebelumnya rendah menjadi berkurang. Penelitian Sabarudin. (2018) tentang efektivitas pemberian edukasi melalui booklet terhadap kepatuhan pengobatan pasien $\mathrm{dm}$ tipe 2 di Puskesmas Puuwatu Kota Kediri. Hasil ratarata kepatuhan responden pre test adalah 2,28 sedangkan setelah diberikan booklet menunjukkan peningkatan rata-rata menjadi 2,70.

\section{Pengaruh Pemberian Informasi Melalui Media Booklet Terhadap Tingkat Kepatuhan Pasien DM tipe 2 di Ruang Kasuari Unit Pelaksana Teknis Rumah Sakit Umum Daerah Bali Mandara}

Hasil uji statistik Wilcoxon Sign Rank Test didapatkan $Z_{\text {hitung }}=5,23>Z_{\text {tabel }}=1,96$ dan $P$ value= $0,001<$ a 0,05 hasil ini menunjukkan bahwa $\mathrm{H}_{0}$ d8itolak yang artinya ada pengaruh pemberian informasi melalui media booklet terhadap tingkat kepatuhan pasien DM tipe 2 di Ruang Kasuari Unit Pelaksana Teknis Rumah Sakit Umum Daerah Bali Mandara. Menurut Notoatmodjo, (2014) pemberian informasi dengan menggunakan prinsip desain pengajaran adalah salah satu upaya untuk menumbuhkan sikap patuh terhadap pengobatan. Dalam penelitian ini peneliti pemberian informasi melalui media booklet kepada responden yang dilakukan selama 45 menit setelah diberikan informasi kemudian responden diberikan booklet untuk dibaca kembali dirumah. Intervensi pemberian informasi melalui media booklet diberikan sebanyak dua kali interval waktu dua minggu, dengan pemberian informasi yang dilakukan oleh peneliti dapat meningkatkan kepercayaan dan kerjasama antara responden dengan peneliti sehingga meningkatkan keyakinan penderita bahwa apa yang disampaikan oleh peneliti baik bagi penderita, dan dapat membentuk niat penderita untuk cepat sembuh dari penyakitnya melalui patuh minum obat.

Menurut Merlin (2017) pemberian informasi melalui pendidikan kesehatan merupakan cara yang tepat untuk mengatasi masalah ketidakpatuhan pasien DM, informasi dapat disampaikan dengan beberapa cara berupa media audio dan visual yang dapat digunakan untuk membantu proses belajar. Pendekatan multimedia selama proses belajar dapat membantu pasien untuk menguasai informasi dengan lebih efektif, salah satu contohnya menggunakan booklet. Booklet dapat dipelajari setiap saat karena berbentuk buku dan dapat menyebarkan informasi dalam bentuk tulisan dan gambar, sehingga terlihat lebih menarik dan sangat sesuai digunakan sebagai media edukasi bagi pasien DM tipe 2 .

Menurut Waluyo (2016) penggunaan media booklet sebagai alat bantu dalam pemberian edukasi kepada pasien DM, akan membuat sasaran pendidikan lebih mudah memahami informasi yang disampaikan dibandingkan penyampaian informasi hanya secara lisan, karena sasaran pendidikan dapat mengamati langsung gambar dan tulisan yang merupakan penjelasan terhadap gambar yang ada dalam media tersebut. Pendidikan kesehatan yang disampaikan melalui metode atau media booklet dapat mempengaruhi individu baik pengetahuan, 
sikap dan perilaku sesuai dengan tujuan dari pendidikan kesehatan tersebut dan pemilihan metode atau media yang tepat atau efektif diperlukan untuk menyampaikan informasi yang tepat.

Peneliti berpendapat pemberian informasi melalui media booklet berpengaruh terhadap kepatuhan pasien DM, karena selain meningkatnya pengetahuan pasien tentang penyakit DM setelah diberikan informasi semakin meningkatnya pengetahuan yang dimiliki responden, maka akan semakin membuat pasien tersebut paham pentingnya melakukan pengelolahaan penyakit DM sehingga nantinya diharapkan dapat membantu meningkatkan kepatuhannya. Pemberian informasi melalui media juga dapat dikatakan sebagi wujud dukungan petugas kesehatan dalam hal ini perawat. Pemberian informasi dan dukungan profesional kesehatan dapat meningkatkan kepatuhan bila dilakukan secara rutin serta terencana. Hal ini sesuai dengan teori menurut Syakira (2014) strategi untuk meningkatkan kepatuhan diantaranya pemberian informasi dan dukungan profesional kesehatan. Pemberian informasi yang jelas pada pasien mengenai penyakit yang dideritanya serta cara pengobatannya dapat meningkatkan pengetahuan, mengubah perilaku, memberikan motivasi dan meningkatkan kepatuhan pasien. Dukungan profesional kesehatan sangat diperlukan untuk meningkatkan kepatuhan, contoh yang paling sederhana dalam hal dukungan tersebut adalah dengan adanya teknik komunikasi. Komunikasi memegang peranan penting karena komunikasi yang baik diberikan oleh profesional kesehatan baik Dokter/perawat dapat menanamkan ketaatan bagi pasien.

Penelitian Valentina (2018) membuktikan bahwa media booklet dapat meningkatkan kepatuhan pada pasien diabetes melitus tipe $2 \mathrm{di}$ Puskesmas Banjarbaru Selatan. Selain itu, penelitian lainnya dengan hasil yang senada juga dilakukan oleh Sabarudin (2018) juga menemukan pemberian edukasi melalui booklet efektif dapat membantu meningkatkan kepatuhan pengobatan pasien DM tipe 2 di Puskesmas Puuwatu Kota Kediri.

\section{KESIMPULAN}

Hasil penelitian menunjukkan ada pengaruh pemberian informasi melalui media booklet terhadap tingkat kepatuhan pasien DM tipe 2 di Ruang Kasuari Unit Pelaksana Teknis Rumah Sakit Umum Daerah Bali Mandara.

Disarankan bagi pelayanan keperawatan agar menggunakan media booklet saat memberikan informasi kepada pasien DM tipe tentang penyakit diabetes mellitus dan terapi pengobatannya, sehingga informasi yang disampaikan dapat lebih mudah dipahami.

\section{DAFTAR PUSTAKA}

Achmad Yoga. (2016). Hubungan Empat Pilar Pengendalian DM Tipe 2 dengan Rerata Kadar Gula Darah. Jurnal Berkala Epidemiologi Volume 11 No. 2

Aris Wibudi. (2015). Obesitas, Diabetes Melitus dan permasalahannya. Jakarta : Fakultas Kedokteran Universitas Indonesia

Bidari. (2014). Strategi Penderita Diabetes Melitus Berumur Panjang. Yogyakarta: Penerbit Kanisius

Brunner \& Suddart, 2014). Buku Ajar Keperawatan Medikal Bedah Edisi 12 Volume 1. Jakarta : EGC

Bustan, Arifin. (2015). Epidemiologi Penyakit Tidak Menular. Jakarta : Rineka Cipta.

Delaune \& Ladner. (2016). Fundamental of Nursing Standart \& Practice Third Edition. Thomsom Delmar Learning. Clifton Park. NewYork

Dinas Kesehatan Provinsi Bali. (2018). Profil Kesehatan Provinsi Bali. Denpasar : Bagian Data dan Informasi

Ernawati. (2013). Penatalaksanaan Keperawatan Diabetes Melitus Terpadu. Jakarta: Mitra Wacana Media.

Hasdianah, R. Rohan. (2016). Mengenal Diabetes Melitus Pada Orang Dewasa dan Anak-anak dengan Solusi Herbal.

Yogyakarta: Nuha Medika

Hastono, Sutanto Priyo. (2016). Modul Analisis Data. Fakultas Kesehatan Masyarakat Universitas Indonesia.

Hayati. (2015). Kepatuhan Berobat Penderita Diabetes Mellitus Tipe 2 di Puskesmas Kecamatan Pancoran Mas 
Jurnal Media Keperawatan: Politeknik Kesehatan Makassar

Vol. 12 No. 12021

e-issn : 2622-0148, p-issn : 2087-0035

Depok. Jurnal Media Keperawatan Indonesia Edisi 3 Volume 2.

Hidayat. (2014). Metode Penelitian dan Teknik Analisis Data. Jakarta: Salemba Medika.

Kementerian Kesehatan Republik Indonesia (2018) Riset Kesehatan Dasar. Jakarta : Badan Penelitian dan

Pengembangan Kesehatan Kementerian Kesehatan RI

International Diabetes Federation. (2018). Diabetes Atlas: Impact On The Individual. (online),

(http://da3.diabetesatlas.org/index68fc.html, diakses 7 Maret 2020).

Merlin, Arozal, W. (2017). Evaluasi Penerapan Booklet dan Edukasi Apoteker pada Pasien Diabetes Mellitus Tipe 2 di

Rumah Sakit Mayapada Tangerang. Jurnal Keperawatan Indonesia Volume 15No. 1

Muninjaya. (2014). Pendidikan Kesehatan Dalam Keperawatan. Jakarta : EGC.

Niven. (2014). Psikologi Kesehatan. Jakarta : EGC

Notoatmojo. (2014). Metodologi Penelitian Kesehatan. Jakarta: Rineka Cipta

Notoatmodjo, (2014). Pendidikan dan Perilaku Kesehatan. Jakarta : Rineka Cipta

Nursalam. (2016). Konsep dan Penerapan Metodelogi Penelitian IImu Keperawatan (2nd ed.). Jakarta: Salemba Medika.

Oktadiansyah dan Yulia. (2018). Gambaran Tingkat Kepatuhan Minum Obat Diabetes Pada Pasien Diabetes Mellitus Tipe 2 di RSUD Cibinong. Jurnal Kesehatan Volume 15 No. 1

Perkumpulan Endokrinologi Indonesia. (2015). Konsensus Pengelolaan dan Pencegahan Diabetes Mellitus Tipe 2 di Indonesia. Jakarta: PB.PERKENI.

Potter \& Perry. (2015). Buku Ajar Fundamental Keperawatan: Konsep, Proses, Dan Praktek, Alih Bahasa : Yasmin Asih. Jakarta : EGC.

Prihaningtyas, Ratna. (2017). Hidup Manis dengan Diabetes-Panduan Lengkap Berkawan dengan Diabetes, Cetakan

1, Media Pressindo, Yogyakarta

Sabarudin. (2018). Efektivitas Pemberian Edukasi Melalui Booklet Terhadap Kepatuhan Pengobatan Pasien DM tipe 2 di Puskesmas Puuwatu Kota Kediri. Jurnal Publikasi Kesehatan Masyarakat Indonesia, Vol. 6 No. 1

Saputra, Lyndon. (2015). Catatan Ringkas Kebutuhan Dasar Manusia. Tangerang : Binarupa Aksara

Smeltzer \& Bare. (2015). Buku Ajar Keperawatan Medical Bedah Brunner \& Suddart. Edisi 8, Vol 1, EGC; Jakarta

Sugiyono. (2016). Metode Penelitian Kuantitatif,Kualitatif dan R\&D (23rd ed.). Bandung: CV Alfabeta.

Susilo \& Wulandari. (2015). Panduan Hidup Sehat Mencegah dan Mengobati Diabetes Mellitus (Edisi Revisi).

Yogyakarta : Aulia Publishing.

Susilana dan Rian. (2014). Media Pendidikan. Bandung: PT. Citra Aditya Bakti

Syakira. (2014). Psikologi Klinis Fakultas Psikologi UMS. Jakarta Fakultas Psikologi Universitas Indonesi

Valentina Meta Srikartika. (2018). Pengaruh Edukasi Melalui Media Booklet Terhadap Pengetahuan Dan Kepatuhan

Pasien Diabetes Melitus Tipe 2 di Puskesmas Banjarbaru Selatan. Jurnal Kesehatan Wiraraja Medika Volume 8 No.1

Waluya, Ahmad. (2016). Hubungan Kepatuhan Pasien Dengan Kejadian Ulkus Diabetik Dalam Konteks Asuhan Keperawatan Pasien Diabetes Melitus di RSUP Dr. Hasan Sadikin Bandung. Jurnal Kesehatan Masyarakat Volume 7 No.1 